\title{
COMMENT
}

\section{THE USE OF NONVIOLENT COERCION: A STUDY \\ IN LEGALITY UNDER ARTICLE 2(4) OF THE CHARTER OF THE UNITED NATIONS *}

\begin{abstract}
Accordingly, if one commonwealth wishes to make war on another and employ extreme measures to make that other dependent on itself, it may lawfully make the attempt ....
\end{abstract}

\section{INTRODUCTION}

The partial oil embargo instituted by certain Arab nations in the wake of the 1973 Yom Kippur War in the Middle East suddenly involved nearly every industrialized nation in the affairs of that troubled section of the globe. For all the shock and surprise voiced by the oil-dependent nations, the Arab move was within the tradition of international coercive policies. International law has long recognized and provided for the use of economic sanctions by one combatant against another during a time of war. Even the employment of economic measures against neutrals, which gained such wide currency during the Napoleonic Wars, has become an accepted part of our vocabulary of "total war."

The Arab policy of regulating the supply of crude oil in response to the customer nation's posture with regard to the Middle East situation was a predictable, but nonetheless important, expansion of this tradition. The embargo was directed at noncombatant nations, after the armed conflict had ostensibly ended. More importantly, there was no suggestion that the economic measures would improve the Arabs' military position. The sanctions were not aimed at influencing a military solution of the Middle East dispute, but rather were intended to alter the relative bargaining positions of the parties in some future political settlement. President Houari Boumediene of Algeria, following a meeting of Arab chiefs of state in November, 1973, is reported to have expressed satisfaction over "the economic, political and military weapons now in the hands of the Arabs." A New York Times article appearing after the close of the confer-

1 B. de Spinoza, Political Treatise, in The Chief Works of Benedict de Spinoza 287, 306-07 (R. Elwes transl. 1887).

${ }^{2}$ N.Y. Times, Nov. 29,1973 , at 1 , col. 6. 
ence reported that the participants had agreed "to exert continued economic pressure on outside countries by manipulating Arab oil exports according to 'the attitude of every country toward the Arab cause." "3

The reaction of international jurists to this expansion of the use of economic coercion is as yet uncertain. This Comment will explore the legality of this type of coercion within the context of the body of international law that has developed around the United Nations Charter. A conclusion reached under Charter law does not, of course, preclude a separate judgment under either customary or other positive international law from being reached independently of the Charter. ${ }^{4}$ But this Comment will consider legal sources outside the United Nations Charter only insofar as they may shed light upon its interpretation.

\section{Article 2(4) and the Realm of International Norms}

International conflict, historically the inevitable result of the lack of congruity in the goals and interests of sovereign States, is perhaps the most formidable topic demanding the attention of the philosopher of world order. To a certain extent, the difficulties inherent in minimizing hostile international confrontations are unlike those attending a similar effort within the confines of a national system. Pacific settlement of disputes at every echelon of human society is facilitated by the presence of a third-party mediator-a person or institution clothed with the authority to regulate such disputes and the strength necessary to implement its regulations. Thus, children turn by instinct to a parent as the final arbiter of sibling controversies, contentious citizens seek a resolution of their differences in courts or chambers of justice, and even otherwise independent states or territories are often bound to bring their conflicts before a federal authority. It is the absence of such a third-party. mediator that has blocked the path to peaceful adjudication of disputes at the international level. A sovereign nation, by the very fact of its sovereignty, is theoretically free to determine its own patterns of action, unfettered by the precepts of any external authority. ${ }^{5}$

${ }^{3}$ Id.

4 For a consideration of economic coercion in the light of non-Charter international legal principles, particularly the principle of nonintervention, see Bowett, Economic Coercion and Reprisals by States, 13 VA. J. INT'L L. 1 (1972).

3 This is, of course, only theoretically true. The notion of absolute sovereignty is at best a metaphysical concept describing a situation in which no nation has ever found itself. The mere existence of other nations implies at least a minimal constraint on the freedom of any particular state. In a multinational world, any member state must consider the feelings of its neighbors before taking action that affects them. To the extent that it must do so it is not free, and to the extent that such a state is not free, it is not truly sovereign. But to say that there are practical constraints upon a nation's freedom of action is a far different thing from saying that there are legal, or perhaps even moral, restrictions on its freedom. The proposition that the principles of international law exist 
Some theories consider the State's freedom to be limited only by the dictates of its own national conscience, and by whatever importance it chooses to ascribe to its international treaties and the amorphous body of international law in general. ${ }^{6}$

The framers of the Charter of the United Nations undertook to tear down this last bastion of the Hobbesian "state of nature." In the few decades preceding the drafting of this document, history had witnessed the tragic results of an interdependent world lacking both viable standards of international conduct and effective sanctions to enforce those standards. The Charter was designed to fill this vacuum.

Foremost in the minds of those drafting the Charter was the necessity of effectively outlawing force as an instrument of international policy. Following a commitment in the Preamble to "save succeeding generations from the scourge of war, which twice in our lifetime has brought untold sorrow to mankind," the heart of the Charter's proscriptions of international violence are contained in article 2, sections 3 and 4 . These provisions direct that:

3.) All Members shall settle their international disputes
by peaceful means in such a manner that international
peace and security, and justice, are not endangered. 4.) All Members shall refrain in their international relations from the threat or use of force against the territorial integrity or political independence of any State, or in any other manner inconsistent with the Purposes of the United Nations. ${ }^{8}$

independently of the respect given them by individual nations is at best arguable and probably unsupported by the history of international behavior. With regard to the individual state, "[n]o rules of international law are binding upon it but those which it has created for itself through its consent. There is no lawgiving authority above it, for there is no state or group of states which can legislate for it." H. Morgenthau, Politics Among NamoNs 301 (4th ed. 1967).

The greatest challenge to this consensual theory is presented by the view that certain principles of international law can legitimately claim a universality derived from the basic axioms of some panhuman morality. Although of considerable persuasive force, this view rests on the concept of a priori norms of international behavior which are inherited by each state at the moment of its assuming statehood. Most nations have not shown a great willingness to accept such a vague, unwritten legacy.

${ }^{6}$ For a discussion of this view and its alternative, see J. BrierLy, THE LAW of Nations 46-57 (5th ed. 1955).

THobbes wrote: "Concerning . . . what is commonly called the law of nations, I need not say anything in this place; because the law of nations, and the law of nature, is the same thing." T. Hobbes, Leviathan 309 (J. Plamenatz ed. 1966). And earlier in the same work: "Where there is no common power, there is no law; where no law, no injustice. Force and fraud, are in war the two cardinal virtues." Id. 145.

${ }^{8}$ Note that neither of these provisions directly refers to war. Apparently the framers accepted the wisdom of substituting "peace" terminology for that employed by the Covenant of the League of Nations which admonished its members "in no case to resort to war." LEAGUE of Nations Covenant art. 12, para. 1. See generally Eagleton, Covenant of the League of Nations and Charter of the United Nations: Points of Difference, 13 DEP'T STATE BuLl. 263 (1945); Goodrich, From League of Nations to United Nations, in THE UNITED Nations 17 (R. Falk \& S. Mendlovitz eds. 1966). 
It is in article 2(4) that the Charter specifically attempts to remove from the international arsenal that weapon which a nation arguably inherits by virtue of its sovereignty-the right to resort to force. Professor Henkin has described article 2(4) as the "principal norm of international law of our time."9 It is at least clear that without this provision the delicate superstructure of the Charter would lack a crucial normative foundation.

An inquiry into the meaning of article 2(4) as a norm of international behavior requires not only an analysis of the substantive content of that norm, to which the bulk of this Comment is devoted, but also a review of the nature of an international norm. Analysis on both levels is complicated on the international plane by the absence of any clear norm-giver or enforcer, and by the common prejudice that principled evaluations of the actions of nations are at best propaganda devices dictated only by expediency. Clearly, then, any international organization which attempts to achieve world order by advocating adherence to certain behavioral norms must first establish both the nature and the correctness of those norms.

The norm expressed by the prescriptive language of article 2(3) and its prohibitive counterpart, article 2(4), may be viewed in a number of ways, each of which entails different conclusions about the legal effect of these sections. First, the norm might be viewed as essentially a matter of convenience-an arbitrary rule, like a regulation governing the due date on a tax return, which may be altered or abandoned without offending any rational imperatives. Under this view, which commands considerable rhetorical appeal, a violation of these sections is a mere technical offense or breach of international etiquette, relatively free of moral culpability. Given the grave potential consequences of international coercion, few nations are apt to view a prohibition against the use of force in international relations so lightly.

A second approach, which attributes slightly greater significance to these sections, sees them not as describing the existing legal situation of the world after the adoption of the Charter, but rather as depicting the way things ought to be. The norm is not a rule governing present conduct, nor is it a measure of accountability for present behavior; it has at best a hortatory effect. An offense against the norm is not a legal offense, but a disappointment of expectations, which cannot realistically be

The serious danger that world leaders could exploit the labors of pedants in drawing fine distinctions within the body of learning known as the "laws of war" induced the framers to circumvent this morass entirely. For a general discussion of the laws of war, see P. Bordwell, The Law of War Between Belligerents (1908); Q. Wright, A Study OF WAR $88,152,329$ (2d ed. 1965).

${ }^{9}$ Henkin, The Reports of the Death of Article 2(4) Are Greatly Exaggerated, 65 AM. J. INT'L L. 544 (1971). 
punished by an international organization. This view, like the first, treats too lightly the present dangers posed by the use of force.

At the other extreme, these sections might be seen to contain some first principle of international relations to which all right-thinking minds must assent, and which would exist independently of both the Charter and any other tenets of international law. An offense against the norm would be an offense regardless of the existence of the Charter: it would violate a dictate of reason that does not need to be reduced to writing to command assent. ${ }^{10}$ Given the ability of rational men to disagree on almost any proposition, however, this view of a universal first principle is a difficult one to defend, and an inadequate foundation for so important a norm. Without some additional support, the defender of a purported norm will find himself totally stymied if his listener fails to accept the self-evident nature of the principle.

Finally, the norm embodied in these sections may express not a necessary, but merely a desirable, condition of civilized interaction among nations. Viewed as such, the norm requires both a practical justification in terms of the existing global situation, and a legal foundation within the confines of international law. The norm prohibiting the use of force is perhaps best viewed in this way. It has a solid legal foundation in the United Nations Charter and receives strong extrinsic support from its importance in the international scene.

Assuming that this last conception of the norm contained in articles 2(3) and 2(4) is the best one, the substantive content of the norm is still quite vague. The framers of the Charter made no attempt to add anything to the definition of "force" in this article to limit the speculations of later commentators. Such related terms as "aggression" and "coercion" were also left undefined. ${ }^{11}$ By not specifying the denotation of the concept of "force," those who drafted the Charter left the meaning of article 2(4) vulnerable to whatever connotation the word has in the minds of those reading it. The resultant situation is rather awkward. Without the United Nations Charter, the world legal situation with regard to international coercion is juridically not

10 To forgo actual statement of the norm, as this view seems to suggest, would violate the widely recognized principle of nullum crimen sine lege. It is perhaps an infirmity of the legal mind that distracts it from giving effect to unproclaimed norms. But experience within a domestic system has upheld the wisdom of not allowing the lawgiver the freedom to punish unspecified offenses. When so viewed, the principle is expressed as nulla poena sine lege. There is no reason to believe that at this point in history any international body will be permitted to punish actions on the ground that they have strayed from an unwritten norm, however rational. For a related discussion, see $G$. $H$. von WRIGHT, NORM AND ACTION: A LoGical INQUIRY 87-88 (1963).

"See Claude, The United Nations and the Use of Force, 1960-61 INT'L Conciliation $323,325$. 
unlike that described by Hobbes. Without article 2(4) the Charter is at best a soulless document, and without some clear understanding of the meaning of this article signatory nations are left guessing at the true import of a behavioral norm they have purported to accept, not only for themselves, but for the rest of the world as well. ${ }^{12}$

This Comment will argue for a broad interpretation of the word "force" in article 2(4) -in particular, its extension to include political and economic coercion. It will take the position that such a reading is legitimate in light of other Charter provisions and related documents; that it is persuasive, given the projected maturation of international norms in response to a continual complication of the global situation; and that it is necessary, in view of the potentially disastrous consequences that may attend a rigid adherence to the narrower prohibition of simple armed force. Before turning to a discussion of the scope of article 2(4), a brief outline of the hierarchies of coercion will be useful.

\section{The Hierarchies of Coercion}

In its search for a viable foreign policy, a nation has at its disposal a number of options which could fairly be listed under the generic heading of coercion or force. These options include several different kinds of coercion, each of which may be implemented on an extremely broad spectrum of intensity and for an almost limitless number of purposes, both licit and illicit. Any conceptual framework used for the classification of international events as permissible or impermissible uses of force must incorporate each of these elements: the nature, the intensity, and the purpose of the coercion. ${ }^{13}$

\section{A. Nature of the Coercion}

International coercion, or the attempt by one independent nation to influence the actions or policies of another by means which extend beyond simple persuasion, can assume a number of forms. Professors McDougal and Feliciano have suggested that the strategies of coercion can be categorized according to the distinctive means employed to influence another nation and the particular ends that are sought. They conclude that the resulting categories will enable us to distinguish between the

12 The basic elements of the world order established by the Charter are imposed on even non-member States. U.N. CharTer art. 2, para. 6.

${ }^{13}$ Of course, to say that a particular instance of the resort to force between nations is impermissible is not necessarily to say that it is therefore illegal. Unless the broader reading of article 2(4) espoused herein is accepted, there are a great many forms of coercion which, barring treaty obligations or an accepted precept of positive or customary international law, could be called imprudent, unjust or even inhuman, but not illegal. 
diplomatic, ideological, economic and military instruments of coercion. ${ }^{14}$ Some grouping along these lines appears sound..$^{15}$ Such categories provide an analytical framework against which we can begin to measure our norms of the permissible or impermissible, legal or illegal use of international force. For our purposes three broad divisions can be highlighted. ${ }^{16}$

\section{Military Force}

Armed warfare is the clearest, and perhaps the oldest, compulsive method of achieving national goals in the world arena. It consists of military conflict between nations or groups of nations and is often accompanied by undisguised invasion of another's territory either for aggressive or defensive purposes. Although listed first here, military force is typically the method of compulsion that is resorted to when less obvious means of coercion have failed to achieve their desired goals.

\section{Intermediate Coercion}

The unmentionable finality of thermonuclear war has perhaps had a chilling effect on the use of all-out military force as an instrument of national policy, at least by the leaders of the world's larger nations. In addition it may be hoped that the fear of triggering nuclear war has led these leaders to recognize the need to avoid even the more conventional (i.e., non-nuclear) genre of armed confrontation. ${ }^{17}$ The search for effective tools of international influence therefore demands an increasing reliance on more subtle, or at least less direct, modes of compulsion.

The history of international relations since 1945 speaks convincingly for the proposition that two states, while not truly at peace, may nevertheless not actually be in a state of war with

14 McDougal \& Feliciano, International Coercion and World Public Order: The General Principles of the Law of War, 67 YALE L.J. 771, 792 (1958) [hereinafter cited as Principles]. This article is the first of a series of three highly recommended pieces on the law of war by the same authors. The others are McDougal \& Feliciano, The Initiation of Coercion: $A$ Multi-Temporal Analysis, 52 AM. J. INT'L L. 241 (1958); McDougal \& Feliciano, Legal Regulation of Resort io International Coercion: Aggression and Self-Defense in Policy Perspective, 68 YALE L.J. 1057 (1959) [hereinafter cited as Regulation]. The articles are reprinted in M. McDougal \& F. Feliciano, Law and Minimum World Public Order (1961).

15 See Special Comm. on the Question of Defining Aggression, 1956 Report, 12 U.N. GAOR, Supp. 16, at 30-33, U.N. Doc. A/3574 (1957).

${ }_{16}$ These categories have been exhaustively examined by McDougal and Feliciano, Principles, supra note 14, and they are mentioned here only by way of introduction. Definitions and discussion may also be found in N. Palmer \& H. Perkins, International Relations 95-240 (2d ed. 1957); The Search for World Order 97-110 (A. Lepawsky, E. Buehrig \& H. Lasswell eds. 1971).

${ }^{17}$ See Dunn, Book Review, 11 World Polrtics 278, 279 (1959):

The recent spectacular developments in military weapons have sharply restricted the utility of coercion as a means of changing the status quo. The destructiveness of nuclear weapons is out of all proportion to any political gains that might be achieved by war. There is no certainty that even mild forms of coercion would not eventually lead to their use. 
each other. They can occupy an intermediate status between these extremes and seek to influence each other by intermediate forms of coercion-that is, by nonamicable measures short of war. ${ }^{18}$ Two notable examples of intermediate coercive instruments which have had some currency in this century are ideological coercion and indirect coercion. Ideological coercion involves the use of hostile propaganda directed at the citizens of a foreign state for any number of reasons-for example, inciting them to revolution, expounding the virtues of the originating state, or discrediting the government of the target state. ${ }^{19}$ Indirect coercion has been characterized by the International Law Commission as including "the fomenting of civil strife by one State in another, the arming by a State of organized bands for offensive purposes directed against another State, and the sending of 'volunteers' to engage in hostilities against another State." 20

The recent concern generated by the extensive use of intermediate coercion has begun to crystallize into more or less accepted norms for its regulation. In certain cases intermediate coercion has been assimilated into the more traditional body of legal theory concerned with the laws of war in general. With regard to other measures unknown to the classic writers, such as the use of ideological coercion, the traditional learning can be applied only by analogy. ${ }^{21}$ If nothing else, this process has demonstrated a certain flexibility in the creation of new normative standards compelled by a change in the complexion of international coercion.

\section{Economic and Political Coercion}

Should a state determine, either from lack of volition or lack of ability, to refrain from the use of direct or indirect military force, it is still not without tools to implement policy in the international sphere. At least two nonviolent modes of influence, the diplomatic (or political) and economic, are still available.

Diplomacy has always been a method, employed with vary-

${ }^{18}$ For an espousal of the "intermediate" terminology see Jessup, Should International Law Recognize an Intermediate Status Between Peace and War?, 48 AM. J. INT'L L. 98 (1954). See generally F. Grob, The Relativity of War and Peace (1949).

${ }_{19}$ For discussions of ideological coercion, see Kelsen, Collective Security Under International Law, International Law Studies 65 (1954); L. Martin, International Propaganda (1958); J. Stone, Legal Controls of International Conflicts 318-23 (1954).

For an exhaustive recent study of this topic see B. MURTy, Propaganda and World PUBLIC ORDER (1968). Note in particular Murty's distinction between persuasion and coercion. Id. 27-32.

${ }^{20}$ Int'l L. Comm'n, Report, 6 U.N. GAOR, Supp. 9, at 9, U.N. Doc. A/1858 (1951).

For a more detailed analysis of the notion of indirect coercion, see Special Comm. on Principles of Int"l Law Concerning Friendly Relations and Co-operation Among States, Report. 20 U.N. GAOR, Annexes, Agenda Item Nos. 90 \& 94, at 77 U.N. Doc. A/5746 [hereinafter cited as Friendly Relations Report]. 
ing degrees of success, of both conveying a nation's wishes to its neighbors and applying pressure toward achieving compliance with those wishes. Professors McDougal and Feliciano explain:

The coercive impact of a use of diplomacy may be the direct result of the content of the communication conveyed .... [Or] [i]t may ... be the net effect of complex diplomatic strategy designed to isolate or encircle the target-state by securing from third states either agreements to support the initiator-state or by inducing them to withdraw or withhold support from the target. ${ }^{22}$

Economic coercion may entail any or all of the traditional methods of economic compulsion. ${ }^{23}$ Although it is by no means novel, this weapon has assumed tremendous importance as the nations of the world have grown to depend upon one another for the requirements of everyday living. Countries relying on world markets for food or industrial raw materials are vulnerable to compulsive measures such as boycotts, embargoes, or attempts by rival nations to feeeze the victim-state's assets or dry up its markets on a global scale. ${ }^{24}$ In addition, the ascendancy of foreign aid has added a new dimension to the realm of international economic persuasion. A nation can employ its foreign aid program coercively by offering aid as a reward for the donee country's pursuit of acceptable policies and by withholding aid (perhaps previously relied on) as a punitive measure to discourage deviation.

The "carrot" model has gained wide acceptance as the basis of an enlightened foreign aid policy. The punitive foreign aid approach, on the other hand, has been criticized as "blunt" and "clumsy." "5 For example, Professor Olmstead notes that

the most effective means of influencing policy in developing countries and of advancing 'our nation's objectives is to grant United States economic assistance to those countries that take necessary internal action to provide a domestic environment conducive to economic and social development within a context of freedom. ${ }^{26}$

${ }^{21}$ See generally F. GROB, supra note 18, at 189-324 (1949).

${ }_{22}$ McDougal \& Feliciano, Principles, supra note 14 , at 792 . That article also contains a short bibliography of the diplomatic instrument of coercion, id. n.74. Seie also R. Aron, PEACr: AND WAR 61 (1966).

${ }^{23}$ For a discussion of these traditional weapons, see N. Palmer \& H. Perkins, supra note 16 . at $160-78$.

${ }^{24} \mathrm{~A}$ curious consequence is that a developing nation with an agrarian economy, although quite susceptible to military or quasi-military aggression, is relatively less vulnerable to economic aggression.

${ }^{23}$ Brown, The Use of Foreign Aid as an Instrument to Secure Compliance with International Obligations, 58 AM. SOC'Y INT'L L. Proc. 210, 214 (1964).

${ }_{26}$ Olmstead, Foreign Aid as an Effective Means of Persuasion, 58 AM. Soc'y INT'L L. Proc. 205, 210 (1964). A similar observation has been offered by Barbara Ward Jackson: 


\section{B. Intensity of the Coercion}

Within each of the three categories mentioned above, coercion can assume a number of intensities. In the area of ideological coercion, for instance, a country may select measures ranging all the way from a mild rebuke of the target nation's actions in the official publications of the coercing government, to extraterritorial broadcasting and airborne pamphleteering ${ }^{27}$ Similarly, a nation may confine its use of armed force to a particular branch of the military, such as the Navy or Air Force, or it may engage in "limited" or "conventional" warfare-which may include permitting only "tactical" (i.e., low-yield) nuclear weapons.

A judgment on the permissibility of coercive action, whether that judgment be moral, practical or legal, must take into account the intensity of the method of compulsion employed in relation to the intended goal and the degree of provocation. Thus, it is possible that even nonviolent methors of coercion, such as the use of propaganda, may be adjudged impermissible when employed without sufficient provocation.

\section{Purpose of the Coercion}

The third element which enters into any consideration of the acceptability of a coercive international policy is the merit of the goal that the nation seeks to achieve. For instance, under the Charter of the United Nations, which purports to outlaw war, the resort to armed force is legitimate only in self-defense against an armed attack ${ }^{28}$ or as a part of a lawful United Nations enforcement action. ${ }^{29}$ Similarly, the suspension of foreign aid as a means of obtaining compensation for entrepreneurs whose overseas assets have been nationalized may command a different legal or ethical judgment than the same act undertaken for the sole purpose of weakening a disfavored political regime.

\section{Conclusion}

Unless all means of coercion are considered illegitimate-a position unlikely to prevail in today's international atmosphere-to say that a particular coercive act is impermissible means that it was undertaken with unnecessary intensity, or for

"The most persuasive pressure is likely to come not from the negative side of refusing aid where reform is lacking but from the positive side of aid generously given when conditions are favorable." Jackson, Foreign Aid: Strategy or Stopgap?, 41 ForeIGN AFFaIRS 90, 101 (1962).

${ }_{27}$ See, e.g., 9 U.N. SCOR, Supp. Apr.-June 1954, at 11-12, U.N. Doc. S/3232 (1954) (government of Guatemala describing airborne pamphleteering by unidentified planes).

28 U.N. Charter art. 51.

${ }^{29} \mathrm{Id}$. art. 39 . For a discussion of the implications of this article, see L. GoOdrich, E. Hambro \& A. Simons, Charter of the United Nations 342-53 (3d ed. 1969). 
an improper purpose. However, there are no rigid categories of the "permissible" or "impermissible" into which a particular action may be placed without delicate sifting and balancing. Perhaps the strongest statement which can be made in a world which ostensibly has accepted the Charter of the United Nations is that the use of armed force, for any purpose not explicitly condoned by article 39 or article 51 of the Charter, ${ }^{30}$. is prima facie illegal regardless of intensity. Another weighty body of opinion would extend the prohibition of armed force to include indirect military and ideological coercion. ${ }^{31}$ But even the limitation on intermediate force is not explicitly authorized by the Charter, and many would argue that a blanket prohibition, without regard to the elements of intensity or purpose, would impose an undesirable rigidity on the affairs of nations. With regard to economic and political coercion, each with its wide range of intensity, the waters become even murkier. It is with the problem of this last, most obscure, level of coercion that the remainder of the Comment will concern itself.

\section{The Scope of Article 2(4)}

In 1965, at the twentieth session of the General Assembly, the Special Committee on Principles of International Law Concerning Friendly Relations and Cooperation Among States submitted a report ${ }^{32}$ which contained an extensive but inconclusive discussion of the merits of reading into article 2(4) a prohibition of the use of economic and political force, at least when it constitutes a threat to the territorial integrity or political independence of the target state. The committee debate focused on four proposals. Two of these proposals, those submitted by Czechoslovakia $^{33}$ and Yugoslavia, ${ }^{34}$ explicitly stated that the principle of article 2(4)'s prohibition of force includes both economic and political pressure. A joint proposal submitted by Ghana, India and Yugoslavia contained the same suggestion, at least by implication. ${ }^{35}$ The United Kingdom, on the other hand,

${ }^{30}$ See notes 28-29 supra \& accompanying text.

${ }^{31}$ See McDougal \& Feliciano, Regulation, supra note 14, at 1059-60.

32 Friendly Relations Report, supra note 20.

${ }^{33}$ Id. 84, U.N. Doc. A/AC.I19/L.6.

${ }^{34}$ Id., U.N. Doc. A/AC.119/L.7. The Czechoslavakian proposal contained the principle that "States shall refrain from economic, political or any other form of pressure aimed against the political independence or territorial integrity of any State." The corresponding section of the Yugoslavian proposal reads: "States shall ... desist from resorting to, or relying upon, force in any of its forms in their relations with other States, and from exerting pressure, whether by military, political, economic, or any other means, against the political independence or territorial integrity of any other State."

${ }^{35}$ Id. 85, U.N. Doc. A/AC.119/L.15: "The term 'force' shall include: . . other forms of pressure, which have the effect of threatening the territorial integrity or political independence of any State." 
sought to limit the meaning of force to armed force ${ }^{\mathbf{3 6}}$ and specifically abjured the inclusion of lesser forms of coercion. ${ }^{37}$

Despite attempts by adherents of both views to marshal arguments from the legislative history of article 2(4) and from its relation to other provisions of the Charter, no consensus on the question was reached. ${ }^{38}$ As is so often the case with documents of this kind, Charter exegesis alone provides no clear resolution of the question. While any acceptable interpretation must rest on firm textual and historical grounds, it must also rest on an analysis of the advisability of a broad interpretation of article 2(4) in light of changes in the world situation since the drafting of the Charter.

\section{A. The Case for a Limited Reading of Article 2(4)}

\section{Charter Exegesis}

Proponents of the view that article 2(4) was never meant to outlaw anything but armed force can turn to the records of the United Nations Conference on International Organization held at San Francisco in 1945. The Brazilian delegation proposed to extend the prohibition of article 2(4) to cover "the threat or use of economic measures in any manner inconsistent" with the United Nations' purposes. ${ }^{39}$ The amendment was rejected, ${ }^{40}$ but the reasons for its disapproval are not clear. During the discussion of the amendment the Belgian delegate suggested that Brazil was underestimating the reach of the phrase "in any other manner," which had been added to the original text. ${ }^{41}$ In addition, the Report of Rapporteur of Committee I to Commission I included a statement that "the unilateral use of force of similar coercive measures is not authorized or admitted." 42 The rejection of the Brazilian amendment may have reflected either opposition to the principle it contained or simply the belief of some of the delegates that the Charter already embodied its

${ }^{36}$ Id. 84, U.N. Doc. A/AC.119/L.8: "2. By the expression 'force' as used in paragraph 1 above is meant armed force. . .."

${ }^{37} I d$. 85. For examples of commentators who believe the term "force" in article 2(4) should be read as "armed force," see N. BENTwich \& A. MARTIN, A Commentary on the Charter of the United Nations 13 (1950); L. Goodrich, E. Hambro \& A. Simons, supra note 29, at 49; L. Henkin, How Nations Behave 149 (1968); 2 L. Oppenheim, INTERNATIONAL LaW 153 (7th ed. H. Lauterpacht 1952).

Broader readings of "force" are to be found in: H. KELSEN, THE UNITED Nations: Ten Years Legal Progress 4-5 (1956); McDougal \& Feliciano, Regulation, supra note 14, at $1059-60$.

${ }^{38}$ For a summary of the arguments presented, see id. 88-90.

${ }^{39}$ Doc. 215, I/1/10, 6 U.N.C.I.O. Docs. 527, 559 (1945).

${ }^{10}$ Doc. 784, I/1/27, 6 U.N.C.I.O. Docs. 331, 334-35 (1945).

${ }^{11}$ Id. 334 .

12 Doc. 885, I/1/34, 6 U.N.C.I.O. Docs. 387, 400 (1945) (emhasis added). 
principle. ${ }^{43}$ Undoubtedly one factor which contributed to the amendment's ultimate rejection was the vagueness of the notion of an "impermissible" use of economic force.

Given the general principle that any one section of the Charter ought not to be read in vacuo but rather as an integral part of the document considered as a whole, a number of arguments can be adduced to support the narrower reading of 2(4). For example, since the inherent right to self-defense of a target state, embodied in article $51,{ }^{44}$ is limited to situations in which an armed attack has previously occurred, reading article 2(4) to include economic or political coercion would seem to create a lacuna in the Charter. A target state could be the victim of an illegal use of force and yet find itself unable legally to exercise its natural right of self-defense. ${ }^{45}$

Article 39 of the Charter sets forth the "situations in which the Security Council may take measures to maintain international peace and security" as those which present "a threat to the peace, breach of the peace, or act of aggression." Unless one is willing to permit the Council to regard a use of economic or political coercion as posing such a threat, the Security Council is powerless to take measures against the state that resorts to these forms of coercion. Read in conjunction with the argument from article 51, this means that a broad reading of article 2(4) would produce a situation in which a state victimized by an illegal use of economic or political force could neither legally take steps in self-defense nor even expect effective help from the United Nations. Supporters of the narrower reading of article 2(4) find in this paradox an indication that the word "force," when used alone, can mean only "armed force." Similarly, other Charter provisions draw a fairly clear distinction between armed force and other kinds of coercion. The preamble says that "armed force shall not be used, save in the common interest," and article 41, which outlines the means by which the Security Council can give effect to its decisions, states: "The Security Council may decide what measures not involving the use of armed force are

${ }^{43}$ Other commentators who regard the travaux préparatoires as ambiguous include ]. Stone, Aggression And World Order 97-98 (1958); Higgins, The Legal Limits to the Use of Force by Sovereign States: United Nations Practice, 37 BRIT. Y.B. INT'L L. 269, 277 n.2 (1961).

${ }_{44}^{44}$ The pertinent part of article 51 reads: "Nothing in the present Charter shall impair the inherent right of individual or collective self-defense if an armed attack occurs against a Member of the United Nations ...." See generally M. Finkelstein \& L. Finkelstein, Collective Security (1966); M. Rangel, Collective Self-Defense and Aggression under the United Nations Charter, 1971 (unpublished thesis in Biddle Law Library, University of Pennsylvania Law School).

${ }^{45}$ This argument is taken from 20 U.N. GAOR, Annexes, Agenda Item Nos. 90, 94, at 88 , para. $53(1965)$. For the response to this argument, see text accompanying notes 53-56 infra. 
to be employed. . . These may include complete or partial interruption of economic relations." This clear distinction of economic pressure from armed force can be interpreted as showing that when the framers wished to refer to both coercive methods, they mentioned both. ${ }^{46}$

\section{Other Problems with an Expansive Reading}

If article 2(4) is read to extend to economic and political coercion, difficulties will undoubtedly arise in separating legal from illegal uses of these forms of coercion. All states attempt to exercise some degree of influence in their normal acts of diplomacy and trade, and certainly not all such attempts should be branded as illegal. Determination of legality would necessarily involve a delicate balancing of such factors as the severity of the action, its objective and its place within a pattern of similarly unacceptable coercive actions. While the difficulty of making such determinations should not prevent us from reading article $2(4)$ to cover economic and political coercion if that reading is in other respects the preferable one, this difficulty must at least be acknowledged as a real factor militating against adoption of such an expansive reading.

Professor Louis Henkin has offered another argument against an expansive reading of article 2(4):

For the present [1963], then, it may serve little purpose to insist that Article 2(4) goes farther than many nations will tolerate. It may be better to leave its authority clear and undisputed to cover at least cases of direct, overt aggression which are generally capable of objective and persuasive proof ... The battle of interventions, for the present, will have to be fought as political battles with little help from law. ${ }^{47}$

Although these remarks were directed to the scope of article $2(4)$ in the area of indirect aggression, whatever weight the argument commands in that context would seem to apply to the still more subtle devices of economic and political coercion. Henkin's argument rests either on the fear that the nations of the world are simply unwilling to accept any inhibitions on their use of nonviolent coercion, or on the fear that the inevitable balancing of motives which would characterize the application of article 2(4) to cases of economic and political coercion would be

${ }^{46}$ This argument is taken from 20 U.N. GAOR, Annexes, Agenda Item Nos. 90, 94, at 88 , para. 49 (1965). For the countervailing argument, see text accompanying notes 49-51 infra.

${ }_{47}$ Henkin, Force, Intervention, and Neutrality in Contemporary International Law, 57 AM. Soc'y INT'L L. PRoc. 147, 158-59 (1963). 
transferred to cases of military force, thereby weakening its effectiveness in the area of military force. In either case, the argument is that rather than turn article 2(4) into an unwieldy behavioral norm, it would be better to bring the full weight of the article to bear on the most conspicuous and dangerous problem-open, armed aggression. ${ }^{48}$

\section{B. The Case for an Expansive Reading}

The basic arguments for expanding the scope of article 2(4) to include some political and economic policies may be reduced to three. They are: that the inclusion of these coercions is legitimate within the textual confines of the Charter; that other international documents drafted since the Charter came into effect demonstrate a growing world sensitivity to the problem posed by the use of political and economic weapons; and that outlawing this genre of coercion can have only a salutary effect on international relations, and may well constitute a necessary step in the evolution of normative standards of international coercive conduct.

\section{Charter Exegesis}

Perhaps the strongest argument for the broad reading of article $2(4)$ is to be found in the language of the provision itself. ${ }^{49}$ Although aware of the many methods by which one modern nation can coerce another, ${ }^{50}$ the framers did not embellish the word "force" with adjectives that would have had the effect of limiting its scope. Instead, they chose to leave it open-ended and adaptable to the inevitable growth and sophistication of coercive measures. The framers were not ignorant of the vagueness inherent in the word "force." Where they meant to say armed force, such as in the preamble and in article 46 , they said armed force. ${ }^{51}$

That article 51 permits self-defense only against a previous

${ }^{48}$ Professor Henkin apparently believes that article 2(4) still has some ascertainable effect in limiting armed conflict. See Henkin, supra note 9. For the opposing view, see Franck, Who Killed Article 2(4)? Or: Changing Norms Governing the Use of Force by States, 64 AM. J. INT'L L. 809 (1970).

19 Many of the arguments set forth in this section were raised in Friendly Relations Report, supra note 20 , at $88-90$, and during the 6 th Committee's consideration of that report, 20 U.N. GAOR, 6th Comm. 870th-894th, 896th-898th meetings (1965).

${ }^{50} \mathrm{But}$ cf. text accompanying notes 39.43 supra \&e sources cited.

5 The only exception to this rule is in article 44 where the word "force" appears without modification, although a reading of that article makes it clear that the only possible interpretation is "armed force." Article 44 provides:

When the Security Council has decided to use force it shall, before calling upon a Member not represented on it to provide armed forces in fulfillment of the obligations assumed under Article 43, invite that Member, if the Member so desires, to participate in the decisions of the Security Council concerning the employment of contingents of that Member's armed forces. 
armed attack $^{52}$ is not necessarily inconsistent with the broad reading of article 2(4). By circumscribing the right to resort to military force, the framers sought to exclude the practice of preemptive or anticipatory attacks ${ }^{53}$ on the part of a soi-disant "threatened" nation. In so doing they narrowed the right of armed self-defense to situations involving prior acts of armed aggression. ${ }^{54}$ But barring military response to nonmilitary aggression does not necessarily condone other aggression or immunize the aggressor from proportionate retaliation or legal sanctions. A victim State may, not inconsistently with the letter or the spirit of the Charter, respond to nonviolent coercion with nonviolent measures of its own, ${ }^{55}$ seek redress before the Security Council, ${ }^{56}$ or both.

Not only the language of article 2(4), but also the expressed purposes and principles of the Charter, support a broad reading. The preamble bespeaks the intention of the signatory nations "to practice tolerance and live in peace with one another as good neighbors." Article 1(1) includes within the purposes of the United Nations the desire "to take effective collective measures for the prevention and removal of threats to the peace, ... and to bring about by peaceful means . . . adjustment or settlement of international disputes or situations which might lead to a breach of the peace ...." Similarly, article 1(2) envisions the development of "friendly relations among nations based on respect for the principle of equal rights and self-determination of peoples ....."

Purely as a matter of consistency, article 2(4)'s textual proximity to sweeping statements of the goals of the organization-which make no attempt to particularize the meanings of terms like "breach of the peace" or "aggression"-suggests that it should be read broadly in order to effectuate those purposes. Why would the drafters, after eloquently expressing their desire for a peaceful, harmonized world, limit the first clear precept embodying this goal to one particular kind of disharmonizing activity-armed warfare? The delegates drafting this instrument were undoubtedly aware that armed conflict was often not the

52 Note 44 supra \& accompanying text.

${ }^{53}$ See Leitel, The United Nations Charter as a Restraint Upon a Nation's Right to Wage War, 36 Brooklyn L. Rev. 212, 226-27 (1970).

${ }^{54}$ But see McDougal, The Soviet-Cuban Quarantine and Self-Defense, 57 AM. J. INT'L L. 507, 598 (1963).

ss For a persuasive argument to this effect, see D. Bowert, SELF-Defense IN INTERNATIONAL LAw 107-08 (1958); Bowett, supra note 4, at 7-8.

${ }^{56}$ The victim-state can ask the Security Council to exercise its broad discretion in determining what is a "threat to the peace, breach of the peace or act of aggression" under article 39 , that is subject to the enforcement measures of article 41 . Nothing in the language of the Charter compels the Council to limit enforcement to situations involving the use of armed force, and any reasonable conception of the Council's role in the containment of international disputes would appear to forbid such a limitation. 
cause of international unrest but rather the purported "cure" for it: a nation will sometimes go to war as a result of extreme nonmilitary provocations. An international Charter seeking to promote international harmony clearly must remove the underlying roots and symptoms of global strife as well as its military manifestations.

The United Nations Charter has a constitutional character, ${ }^{57}$ and it is an axiom of constitution-drafting that the instrument must be imbued with enough force and clarity to make it effective, and yet have enough flexibility and expansiveness to ensure against obsolescence. The framers were undoubtedly aware of the possibility that new forms of international coercion would rise to prominence in future generations. They must also have known that these changes in the complexion of international compulsion would in no way diminish its inflammatory character or the attending dangers to world peace. The language of article 2(4) had to be open-ended if it was to remain effective as a behavioral norm; the history of the United States Constitution has shown the necessity of formulating new protections for liberty as new dangers to it arise. ${ }^{58}$ Similarly the Charter of the United Nations must either permit or even encourage the evolution of norms that are responsive to new dangers, or be relegated to the status of an irrelevant historical document. Such an event would clearly be repugnant to the spirit of the Charter and to the intention of those who wrote it.

\section{Other International Documents}

The search for an understanding of the meaning of the term "force" in article 2(4) need not be confined within the four corners of the Charter itself. Extraneous sources offer evidence of the kinds of nonamicable influence which are presently occupying the attention of draftsmen of international documents. While these sources cannot directly affect the meaning of article 2(4) they do evidence world recognition of the need to define more precisely the notion of impermissible coercion, and offer some indication of current trends of thought in this regard. The United Nations, insofar as it purports to embody world opinion on the measures necessary to insure peace, cannot easily ignore these manifestations of concern. It will suffice for the purposes of this Comment to mention briefly three contexts in which the abuse of economic and political power has been considered: the search for a workable definition of aggression; General Assembly

\footnotetext{
57 See I. Claude, Swords Into Plowshares ch. 9 (1956).

${ }^{58}$ See, e.g., Olmstead v. United States, 277 U.S. 438, 471 (1928) (Brandeis, J., dissenting).
} 
resolutions speaking directly to the subject of nonmilitary coer-cion; and international treaties that touch upon the same subject.

\section{a. The Elusive Definition of Aggression}

The history of the United Nations has been marked by repeated attempts to define the term "aggression." These apparently Sisyphean efforts have sprouted a voluminous literature dealing not only with the merits of particular proposed definitions, but also with the wisdom of even attempting the task. ${ }^{59}$ It is not the purpose of this section to summarize this literature, but rather to point out what seems to be a growing awareness of the need to expand the concept of aggression to encompass forms of coercion other than open armed attack. ${ }^{60}$

The Conventions for the Definition of Aggression, ${ }^{61}$ signed in 1933 by the Soviet Union and its neighbors, provide a convenient example of the early view of aggression as limited to the use of undisguised military force. Article II of the Conventions defines aggression as a declaration of war, an armed invasion, an attack by land, naval or air forces, a naval blockade, or aid to armed banks invading the territory of another state. Economic and political coercion were mentioned only as inadequate justifications for aggression, in article III. This Soviet view became the model for much of the League of Nations' definitional efforts and for some regional and bilateral treaties drafted during the 1920's and ' 30 's. ${ }^{62}$

With the exception of a definition of aggression offered by the Phillipines at the San Francisco Conference in $1945,{ }^{63}$ which

${ }^{59}$ Some highlights of the literature on aggression are: J. STONE, supra note 43 (a comprehensive study of the United Nations work in this area); A. THOMAs \& A. J. Thomas, The Concept of Aggression In International Law (1972); The General Problem of Defining Aggression, 2 GA. J. INT'L \& CoMP. L. 1 (Supp. 1 1972); Hazard, Why Try Again to Define Aggression?, 62 AM. J. INT'L L. 701 (1968); Sohn, The Definition of Aggression, 45 VA. L. REv. 697 (1959); Harvard Research in International Law, Draft Convention on Rights and Duties of States in Case of Aggression, 33 AM. J. INT'L L. 819-909 (1939); Wright, The Prevention of Aggression, 50 AM. J. INT'L L. 514 (1956); Wright, The Concept of Aggression in International Law, 29 AM. J. INT'L L. 373 (1935).

${ }^{60}$ This observation is not original. See, e.g., Hazard, supra note 59, at 708:

From the early years when attention of the draftsmen was focused primarily upon 'force and threat of force,' and a narrow interpretation of 'force' as being only 'armed force,' the draftsmen have moved far. Now there are claims that 'force' takes many forms, and 'arms' can be of several kinds. All present danger to sovereignty to those against whom they are used.

61 The Conventions were signed by the U.S.S.R. and by Afghanistan, Estonia, Latvia, Persia, Poland, Rumania, Czechoslovakia, Turkey and Yugoslavia. July 3, 1933, 147 L.N.T.S. 67 ; July $4,1933,148$ L.N.T.S. 211 . The language of the Conventions tracks that of a Soviet proposal to the Committee on Security Questions of the 1933 Conference for the Reduction and Limitations of Armaments. The text may be found in Secretary General Report, 7 U.N. GAOR, Annex, Agenda Item No. 54, at 34-35, U.N. Doc. A/2211 (1952), which lists the attempts to define aggression up to 1952.

${ }^{62}$ See J. Stone, supra note 43 , at 34-38.

${ }^{63}$ Doc. 2, G/14(k), 3 U.N.C.I.O. Docs. 535, 538 (1945). The delegates at San Francisco ultimately decided not to include a definition of aggression in the Charter, Doc. $881,111 / 3 / 46,12$ U.N.C.I.O. Docs. 502, 505 (1945). They chose instead to let the Security Council grapple with the problem under article 39. 
would have condemned indirect coercive measures and certain forms of ideological aggression, it was not until the early 1950's that any significant expansion of the concept of aggression entered the picture. In 1951, the International Law Commission submitted its Report on The Question of Defining Aggression. ${ }^{64}$ Neither in its consideration of the definition of aggression nor in its Draft Code of Offences Against the Peace and Security of Mankind was the Commission willing to extend the concept of aggression substantially beyond that contained in the 1933 Conventions. But by the time the Sixth Committee met in 1952, representatives of the smaller nations, notably the Latin American bloc, had begun to press for a broad definition that would include economic, cultural and ideological aggression as threats to a nation's sovereignty. During the course of the Sixth Committee's debates, the Afghan delegation took the position that economic aggression was "perhaps the most dangerous of all" forms of aggression, and refused to accept any definition that did not make specific mention of economic aggression. ${ }^{65}$ The Argentine delegation concurred in the belief that a definition which did not take into account economic force would be valueness. ${ }^{66}$

A 1953 Soviet draft definition ${ }^{67}$ provides the most comprehensive codification of the fears expressed by some nations that economic and political aggression would replace, without a great difference in result, the use of armed force as a means of fulfilling national policies. Subdivision 3 of the U.S.S.R. Draft Resolution reads:

That State shall be declared to have committed an act of economic aggression which first commits one of the following acts:

(a) Takes against another State measures of economic pressure violating its sovereignty and economic independence and threatening the bases of its economic life;

(b) Takes against another State measures preventing it from exploiting or nationalizing its own natural riches;

(c) Subjects another State to an economic blockade.

The Soviet proposal also contained definitions of indirect and ideological aggression, and a section which would have permitted the Security Council to declare any other act not

${ }^{64}$ Int'l L. Comm'n, Report, supra note 20.

657 U.N. GAOR, 6th Comm. 145 (1952).

6s Id. 171 .

${ }^{67}$ U.N. Doc. A/AC.66/L.2/Rev.1 (1953).The text of the Soviet draft is contained in Special Comm. on the Question of Defining Aggression, Report, 9 U.N. GAOR, Supp. 11, U.N. Doc. A/2638 at 13-14 (1953) [hereinafter cited as Aggression Report]. 
specifically listed in the proposal "to be an attack or an act of economic, ideological or indirect aggression."68

The debates on the definition of aggression, continuing well into the middle 1960's, evidence an intense concern on the part of third world nations with the effect of economic and political weapons, and a belief on the part of those nations that some international restriction of these weapons is desirable. The Bolivian delegate noted in 1953 that "[a]rmed aggression was a recourse to force, economic aggression was a recourse only to pressure, but it could lead a country not only to civil war and loss of independence, but also to reduce it to poverty and famine."69 A similar sentiment has been expressed by the delegate from Dahomey:

At the present day, economic aggression is the most common form of aggression. . . By adopting coercive economic measures and by using economic pressures, the industrialized countries could imperil the economic and hence the political independence of the developing countries. This form of aggression is contrary to certain principles of the United Nations. ${ }^{70}$

There has recently been a trend toward separating the problem of economic and political coercion from the debate over the definition of aggression, ${ }^{71}$ and concentrating on incorporating these measures into the general understanding of article 2(4). A 1971 draft proposal submitted by the U.S.S.R. on the question of the definition of aggression abandoned reference to economic aggression and merely added a proviso that other acts may be deemed to constitute aggression if they are declared to be such by the Security Council. ${ }^{72}$ The omission of economic and political coercion in the reports of the latest Special Committees on the Question of Defining Agression ${ }^{73}$ appears to reflect a decision that, in the future, these bodies will restrict themselves

${ }^{68}$ Aggression Report, supra note 67, U.N. Doc. A/2638 at 13.

${ }^{69}$ Id., U.N. Doc. A/2638 at 8-9. A prior Bolivian draft resolution included in the definition of aggression "unilateral action whereby a State is deprived of the economic resources derived from the proper conduct of international trade, or its basic economy is endangered." Id. 15, U.N. Doc. A/AC.66/L.9. The Bolivian delegate asserted that economic aggression violated fundamentally three basic principles of the United Nations: the principle of the political independence of States, that of their sovereign equality and that of non-interference in their domestic affairs. . . . Political independence was closely linked with economic independence; thus anything which threatened economic independence was as much an act of Id. 8 . aggression as was armed aggression.

${ }^{70}$ Contained in a note verbale from the Dahomey Ministry of Foreign Affairs, dated

22 February 1965, U.N. Doc. A/AC./91/4 (1965).

71 Bowett, supra note 4 , at 3 n.12.

7226 U.N. GAOR Supp. 19, at 23, 24; U.N. Doc. A/AC.134/L.12 (1971).

${ }^{73} 28$ U.N. GAOR Supp. 19, U.N. Doc. A/9019 (1973); 26 U.N. GOAR Supp. 19, U.N. Doc. A/8419 (1971). 
to formulating a definition of armed aggression. Undoubtedly in response to the utter failure of these definitional forays, those interested in calling attention to impermissible forms of coercion have resorted to General Assembly resolutions to express their concerns.

\section{b. Resolutions of the General Assembly}

In the course of its proceedings the General Assembly of the United Nations periodically adopts resolutions and declarations which provide a convenient barometer of world concern with international coercion in its various guises. As was the case with the proposed definitions of aggression, these General Assembly pronouncements have over the years grown more and more critical of several methods of nonviolent coercion that have increasingly made themselves felt in the arena of international relations.

Two early General Assembly resolutions exemplify the uncertain attitude of the late 1940's and early 1950's toward coercions short of armed attack. Although the texts of those resolutions do not limit themselves to armed force, they contain no specific mention of other forms of coercion. A 1949 resolution called upon all nations " $[t]$ o refrain from any threats or acts, direct or indirect, aimed at impairing the freedom, independence or integrity of any State ..." In a similar vein a 1950 resolution contained the assertion that "whatever the weapons used, any aggression . . . is the gravest of all crimes against peace and security throughout the world . . .."75

By 1965, the delegates had begun to show concern over the proliferation of nonviolent forms of coercion. They specifically condemned such lesser coercions in a Declaration on the Inadmissibility of Intervention in the Domestic Affairs of States and the Protection of Their Independence and Sovereignty:

1.) ... [A]rmed intervention and all other forms of interference or attempted threats against the personality of the State or against its political, economic and cultural elements, are condemned.

2.) No State may use or encourage the use of economic, political or any other type of measures to coerce another State in order to obtain from it the subordination of the exercise of its sovereign rights or to secure from it advantages of any kind . . . ${ }^{76}$

The same wording was included five years later in a Declaration

${ }^{71}$ Essentials for Peace, G.A. Res. 290, U.N. Doc. A/1251 at 13 (1949).

${ }^{75}$ Peace Through Deeds, G.A. Res. 380, 5 U.N. GAOR Supp. 20, at 13, U.N. Doc. A/1775 (1950).

${ }^{76}$ G.A. Res. 2131, 20 U.N. GAOR Supp. 14, at 11, U.N. Doc. A/6014 (1966). 
on Principles of International Law Concerning Friendly Relations and Co-operation Among States in Accordance with the Charter of the United Nations. ${ }^{77}$ Equally explicit was this language from a 1969 resolution:

The United Nations Conference on the Law of Treaties ... . Solemnly condemns the threat or use of pressure in any form, whether military, political, or economic, by any State in order to coerce another State to perform any act relating to the conclusion of a treaty in violation of the principles of the sovereign equality of States and freedom of consent .... ${ }^{78}$

There appear to be two strains running through these pronouncements. Some condemn economic coercion as a weapon-that is, as an instrument for forcing another nation to adjust its national policy or foreign posture. Others in economic coercion may be accomplished by any method of compulsion, so long as it is aimed at securing economic advantages over or concessions from the victim State. In one context, the term refers to the nature of the means used; in the other, to the character of the goals sought. Of course, the two meanings are often merged in practice. Economic weapons invariably produce economic effects, while an attack upon a nation's economy will often result in undermining its governmental or political structure.

\section{c. Treaties}

Since the drafting of the United Nations Charter in 1945, a great number of bilateral and multilateral treaties have reaffirmed the signatories' commitment to the principles it expressed. ${ }^{79}$ Some of these documents have elaborated on the wording of article 2(4) with regard to the prohibited methods of coercion. Such documents typically either enumerate the pros-

77 G.A. Res. 2625, 25 U.N. GAOR Supp. 28, U.N. Doc. A/8028 at 121, 123 (1971). While clearly deploring the use of economic coercion as a means of attaining international objectives, the resolution put its condemnation in terms of the principle of non-intervention and not specifically under article 2(4).

The issue of the proper characterization of economic coercion caused continuing debate in the Special Committee on Principles of International Law Concerning Friendly Relations and Co-Operation Among States. For a summary of the Special Committee's efforts in this area see its Report, 24 U.N. GAOR Supp. 19, U.N. Doc. A/7619 at 31-33 (1969). For a discussion of the significance of the use of the terminology of nonintervention rather than that of article 2(4), see Bowett, supra note 4, at 1-2.

${ }^{78}$ Resolution Relating to the Declaration on the Prohibition of Military, Political or Economic Coercion in the Conclusion of Treaties, 24 U.N. GAOR, Annexes, Agenda Item No. 94, at 1, U.N. Doc. A/7697 (1969).

${ }^{79}$ For a complete list of pre-1963 international documents that reaffirmed the principles of the Charter, in particular article 2(4), see I. BrowNLIE, INTERNATIONAL LAW AND THE USE OF Force BY States 127-29 (1963). 
cribed measures or refer vaguely to "coercion," leaving to implication the extension beyond the simple use of armed force.

A notable example of the former class of instruments is the Charter of the Organization of American States, article 19 of which reads: "No State may use or encourage the use of coercive measures of an economic or political character in order to force the sovereign will of another State and obtain from it advantages of any kind." ${ }^{30}$ The indirect reference to nonmilitary intervention is illustrated by the Declaration on the Promotion of World Peace and Co-operation promulgated at the Conference of African and Asian States held at Bandung in $1955 .^{81}$ The declaration contains the principle of "Abstention by any country from exerting pressures on other countries." 82

The documents referred to in this and the preceeding sections evidence a growing concern over the dangers of economic and political coercion-particularly among the less developed nations-which have a special interest in fostering a coercion-free international atmosphere in which to pursue their economic and political development. If article 2(4) is to remain a meaningful norm of international conduct, it must reflect this growing concern.

\section{A Broad Reading of Article 2(4) as a Step in the Evolution of Norms of International Conduct}

It is difficult to evaluate the argument advanced by Professor Henkin that an expansive reading of article 2(4) may undermine its overall effectiveness. ${ }^{83}$ That argument could find two justifications: concern that the inevitable balancing of motives and intensities that would attend the application of the norm to instances of economic and political coercion would transfer to other judgments under article 2(4), preventing automatic condemnation of even overt military aggression; or anxiety that an irksome extension of article 2(4) would induce many states to repudiate the norm altogether, jeopardizing present success in the area of military force. Upon consideration, however, neither of these fears seems compelling. With respect to the first, there is presently no evidence to indicate that balancing in regard to economic and political coercion would taint the consideration of clear military violations of article 2(4). And with respect to the second, there is certainly no doubt that the word "force" in

${ }^{80} 2$ U.S.T. 2394; as amended, Feb. 27, 1967, 21 U.S.T. 607; 119 U.N.T.S. 3.

811955 Documents on INTERNational AFFairs 435. For a list of international instruments which have affirmed the principles promulgated at The Bandung Conference, see I. BrownLIE, supra note 79, at 119-20 n.4.

${ }_{82} 1955$ DOCUMENTS ON INTERNATIONAL AfFairs 436.

${ }^{83}$ Text accompanying note 47 supra. 
article 2(4) covers armed force. The inclusion of other categories, even if they are not universally accepted, seems more likely to result in a gradual strengthening and broadening of the norm's effect on the policy determinations of national leaders. Nations, like individuals, often find themselves reluctantly growing to accept propositions which at first blush were rejected as totally impractical. ${ }^{84}$

The question whether to include economic and political coercion within article 2(4)'s proscription must therefore turn on the felt necessity to develop among nations a commitment to refrain from these forms of force. That many nations seek such a commitment is demonstrated by the expanded notions of force included in the international documents described in the previous section. The probability that other nations will eventually accede to a ban on at least some economic and political weapons is perhaps best demonstrated by describing briefly several recent examples of alleged economic and political aggression, and the reactions of the alleged target nations. ${ }^{85}$

Egyptian interference with Israeli-connected ships passing through the Suez Canal was heavily debated in the Security Council in the 1950's. ${ }^{86}$ The Egyptian action was eventually condemned not as aggression, but rather as a violation of the armistice agreements between Israel and neighboring Arab states. The draft resolution, ${ }^{87}$ presented jointly by the delegations of France, the United Kingdom and the United States, contained the following provision:

[T]he restrictions on the passage of goods through the Suez Canal to Israel ports are denying to nations at no time connected with the conflict in Palestine valuable supplies required for their economic reconstruction, and ... these restrictions together with sanctions applied by Egypt to certain ships which have visited Israel ports represent unjustified interference with the rights of nations to navigate the seas and to trade feely with one another, including the Arab States and Israel . . . 88

A Cuban accusation of economic aggression arose in 1960 in

${ }^{84}$ Robert $W$. Tucker has written that "[i]t is naivete, not sophistication, to believe that the conviction statesmen and nations profess and the justifications they urge in defense of their actions have no effect on the policies they pursue." (quoted in R. FALk, Law, MORality, and War in THE Contemporary World 32 (I963)).

${ }_{85}$ For a list of situations in which complaints of economic aggression were raised in the Security Council, see D. BoweTt, supra note 55, at 106 n.3 (1958).

${ }^{86}$ See, e.g., 6 U.N. SCOR, 549th-558th meetings (1951); 9 U.N. SCOR, 658-664th, 682nd-688th meetings (1954).

${ }^{87} 6$ U.N. SCOR, 558th meeting, U.N. Doc. S/2298/Rev. 1 (1951).

${ }^{88}$ Id., U.N. Doc. S/2293/Rev. 2-3. This resolution was adopted by a vote of 8-0, with 3 abstentions, id., U.N. Doc. S/2298/Rev. $3 \& \mathrm{n} .1$, and subsequently issued as U.N. Doc. S/2322 (1951). 
response to the United States' reduction of the Cuban sugar quota and decision to cease refining of Cuban crude oil. The Cuban delegate to the Security Council, after describing economic aggression as an "international crime" added:

The accusations made and the punitive measures proposed [by the United States] have . . . ranged from the elimination of the sugar quota-economic aggression- to the landing of marines-military aggression. For over eighteen months the people of Cuba have been subjected to a policy of intimidation, coercion and threats ....89

Ecuador voiced similar accusations of illegal economic and political force when the United States suspended sales of military material to Ecuador in response to that country's seizure of fourteen American tuna boats within its claimed territorial waters. ${ }^{90}$

More recently, there have been claims that American economic policies effectively. undermined the stability of the Marxist Allende government in Chile and eventually contributed to its downfall. An article published before the Chilean coup described the United'States' measures as follows:

Economic pressure on Chile has taken the form of cutting U.S. and "international" lines of credit to the Allende government. Two examples of this response present themselves. Chile's application for a small loan from the Export-Import Bank for the purchase of commercial passenger aircraft from Boeing (a U.S. firm) for the Chilean National Airlines was denied. As a result the United States has forced Chile to consider alternative European producers, perhaps a minor inconvenience. U.S. representatives within the InterAmerican Development Bank reacting to threats to reduce or withhold U.S. funds to IDB because of its willingness to listen to Chilean requests for development loan funding have "delayed" Chilean requests (which has the same effect as an overt denial). U.S. AID funds have not been either requested or suggested in the case of Chile since the end of the Frei regime.

The over-all purpose of U.S. policy is to create economic dislocation and provoke a domestic social

${ }^{89} 15$ U.N. SCOR, 874th meeting at 6 (1960). For the United States' denial that its actions constituted economic aggression, see the remarks of Ambassador Lodge, id. 27-32

${ }^{90}$ See Java, $A$ Review of the Progress and Problems of the Organization of American States, 65 Dep't State Bull. 284, 287 (1971). 
crisis that could lead to either the overthrow of the Allende government by a civil-military coalition made up of the Army, the Christian Democrats, and the extreme right-wing National Party, or the discrediting of the government and its defeat in the 1973 congressional elections, thus undercutting the basis for future changes. ${ }^{91}$

These alleged incidents of economic and political aggression demonstrate that economic and political weapons of coercion, like military weapons, can impair a nation's sovereignty and give rise to the resentment, humiliation and lasting damage that breed international tension. The anxiety of the coerced nation watching its economic life or political status be overwhelmed by the encroaching policies of another nation is understandable, as is the tendency of the victim to seek aid from its international friends-particularly members of the large power blocs.

As the recent Arab oil embargo demonstrates, the more powerful nations themselves are no longer immune to economic coercion. Indeed, the incident provides a striking preview of a possible future in which the industrialized nations gradually exhaust their domestic resources, and fall prey to manipulation by the nations to which they must look for substitutes. Nor are the tools of economic coercion available to the lesser developed nations and their industrialized neighbors limited to control of natural resources: concern has recently developed, for example, over the use of stockpiles of another nation's currency as a potential threat to its value. ${ }^{92}$

Economic and political coercion pose genuine threats to international harmony, and the vulnerability of the militarily powerful industrialized nations compounds the dangers. In a lecture delivered at the Geneva Institute of International Relations in 1930, Professor Andre Seigfried spoke of the need to develop a "code of international economic morality." 93 In 1974, even more than in 1930, that need is a compelling one, and a step toward its fulfillment would be the inclusion of economic and political force within article 2(4)'s proscription.

\section{Implications of an Expansive Reading of Article 2(4)}

To say that article 2(4) covers economic and political coercion as well as military force is not to say that every instance of

91 Petras \& LaPorte, Can We Do Business With Radical Nationalists? Chile: No, 7 For. Policy 132, 137, 139 (1972). But see Sigmund, The "Invisible Blockade" and the Overthrow of Allende, 52 For. AfFairs 322 (1974).

${ }^{92}$ See Will the Arabs Use the Money Sword?, Forbes, Dec. 15, 1973, at 31.

${ }^{93}$ Seigfried, Economic Causes of War, Geneva Institute, Problems of PeAce 97-98 (5th ser. 1930). 
economic or political influence is a violation of the Charter. The disputed actions described in the previous section all are colorably legitimate. If one were asked to render a legal opinion on actions of a similar nature between two competing merchants, the conclusion would be dictated generally by the principle of reedom of contract: within the broad confines of "fair" business f actices, American law offers no relief to the businessman v: timized by intense, even predatory, competition. Similarly, incernational law, even the law of the Charter, does not presume to alter the essentially gladiatorial theory of survival that governs international trade, as long as the stakes remain commercial. It is only when a nation undertakes to use its economic power "against the territorial integrity or political independence of any State, or in any other manner inconsistent with the Purposes of the United Nations" ${ }^{14}$ that the norm of article 2(4) is violated.95

This is admittedly a vague standard, and the difficulties involved in drawing lines between proper and improper forms of economic and political coercion are formidable. But these difficulties are not insurmountable. There has been some success in a similar search for the earmarks of "intermediate" coercion, and there is every reason to believe that, given time and thought, similar progress will be made in the area of economic and political coercion. Only a few preliminary remarks in this regard will be offered here.

The precise scope of a proscription on the use of economic and political force must turn on the legal and practical justifications for limiting the use of economic and political power in the international arena. The United Nations Charter proclaims the right of self-determination of peoples" and "the sovereign equality of all its Members." ${ }^{27}$ It is this sovereignty that distinguishes a nation from an individual merchant within a particular nation. When the individual considers himself wronged but the courts deny him a remedy, it is because an acknowledged superior entity-the State-has determined that the alleged transgressor is in possession of a greater right. On the international plane, the principle of national sovereignty is superior to all others, and the Charter declares that it be subordinated to none.

There is also a serious practical difference between commercial and international disputes. The danger that a businessman

94 U.N. Charter art. 2, para. 4.

9s At least one commentator has read the last part of article $2(4)$ as a clear limitation on the proscription which precedes it: "Article 2(4) does not forbid the threat or use of force' simpliciter; it forbids it only when directed 'against the territorial integrity or political independence of any State, or in any other manner inconsistent with the purposes of the United Nations.' " J. STONE, supra note 43, at 95.

${ }^{96}$ U.N. ChARTER art. 1, para. 2.

${ }^{97}$ U.N. CharTer art. 2, para 1. 
victimized by competition will resort to forceful self-help in remedying the situation is minimized by the presence of the local police and courts which stand ready to punish any such violent retaliation. There are no effective international counterparts to these institutions. We must therefore contend with the increased probability that a victim nation will seek to redress, with armed force, an impairment of its sovereignty achieved by economic means. It is this possibility of military retaliation, always at least theoretically within the reach of an offended state, which justifies the imposition of legal restrictions on economic freedom.

In the final analysis, relatively few types of conduct would constitute violations of article 2(4). Not only must such economic or political coercion be undertaken for impermissible purposes; it also must be of sufficient intensity to pose a genuine threat to the sovereignty of the target state. If not of that intensity, the coercion would best be dealt with, in the words of one author, "not [as] an international crime, but [as] an international tort."98

Of course, the present state of Charter law, proscribing force only when it is used for the purposes listed in article 2(4), is not a necessary, or perhaps even a wise, limitation in the case of economic coercion. Even under the broad reading of article 2(4) urged in this Comment, international law would not pass judgment on economic policies not intended to impair the sovereignty of other nations, even if these policies otherwise forced the affected state into the direst of circumstances. The desire to interfere with the sovereignty of another state is not the only motive that can prompt hostile economic action: greed, or simple envy may provide an equivalent inducement. ${ }^{99}$ As long as the resort to war remains an appealing response to destructive economic policies, whatever their motivation, the community of nations will need to continue refining its standards of economic behavior.

\section{Conclusjon}

Examination of the language and historical background of article 2(4) provides no clear indication of its intended meaning. The vagueness of article 2(4)'s prohibition requires that its present scope be determined by reference to modern notions of what are permissible and impermissible forms of coercion, and it is in this respect that the argument for a broad reading of article 2(4) is most compelling. The nations of the world are growing to

\footnotetext{
${ }^{98}$ Higgins, supra note 43 , at 276 (footnotes omitted).

${ }^{99}$ For example, the United States, which supplies Japan with vital soybeans, might choose instead to sell soybeans to a nation which offered a higher price. The motive would be purely greed-a desire to maximize profits-but the effect on Japan would be no different than if the motive were a desire to interfere with the policies of the Japanese government.
} 
realize, as indeed they must, that economic and political coercion, like military coercion, can impair the target State's sovereignty and create the kinds of feelings of which international fear and tension are made. And as the events of this century have so clearly demonstrated, tension among nations is, like jealousy, a monster which "doth mock the meat it feeds upon." 